\title{
HERBAGE YIELD AND QUALITY TRAITS OF DIFFERENT ALFALFA (MEDICAGO SATIVA) CULTIVARS
}

\author{
Ozkan Harmanlıglu ${ }^{1}$, Mahmut Kaplan ${ }^{1, *}$ \\ ${ }^{1}$ Erciyes University, Faculty of Agriculture, Department of Field Crops, Kayseri, Turkey
}

\section{Natural Sciences}

\begin{abstract}
This study was conducted to determine and compare herbage yield and quality traits of different alfalfa (Medicago sativa L.) cultivars under provincial conditions of Kayseri, Turkey. For this purpose, 16 different alfalfa cultivars (Verdor, Özpinar, Verko, Sünter, Kayseri, Savaş, Gea, Ömerbey, Magna-601, Alsancak, Başbă̆, Nimet, Bilensoy, Magnum-5, Elçi and Gözlü) were used as the plant material. Experiments were conducted in randomized blocks design with three replications in Kayseri province during the growing seasons of 2014-2015. Significant differences were observed in herbage yields and quality traits of alfalfa cultivars $(p \leq 0.01)$. Current findings revealed that plant heights varied between $55.75-84.83 \mathrm{~cm}$, green herbage yields between $5125.80-7388.96 \mathrm{~kg} / \mathrm{da}$, dry herbage yields between 1349.30 - $1878.86 \mathrm{~kg} / \mathrm{da}$, crude protein yields between 243.04 - $283.44 \mathrm{~kg} / \mathrm{da}$, crude protein ratios between 16.57 $20.28 \%$, crude ash ratios between $9.41-10.52 \%$, acid detergent fiber (ADF) ratios between $34.57-42.27 \%$ and neutral detergent fiber (NDF) ratios between 46.89 - 55.21\%. Gea and Alsancak alfalfa cultivars were found to be prominent for green herbage, dry herbage and crude protein yields, thus these cultivars were recommended for Kayseri province and similar ecologies.
\end{abstract}

Keywords: alfalfa, cultivars, nutritive value, yield

\section{INTRODUCTION}

Livestock industry is an essential component of agricultural sector (Ahmad et al., 2016) and sufficient quality feed supply is the greatest limiting factor in livestock productions. Development of livestock industry largely depends on efficient use of agricultural lands and feed sources. Climate, growing conditions, feed technologies and genetic variations greatly influence nutritional attributes of the feeds (Younas and Yaqoob, 2005). Feed crops constitute the primary source to improve productivity in livestock operations. Feed crops constitute a cheap source of feed for animals, contain nutrients required for rumen flora, rich in vitamins and minerals, improve reproductive power of animals and thus allows animals to provide high yields and quality products. Therefore, feed crops have quite a significant place in animal nutrition (Engin and Mut, 2017). The feed sources with low protein content and digestibility result in low yields and quality in livestock feeding, thus recent researches mostly focused on quality of feed sources (Ahmad et al., 2016).

Alfalfa (Medicago sativa L.) is among the most important perennial feed legumes worldwide. Multiple harvests, high quantity and quality herbage yields, high adaptation capacity to different climate conditions, long-lasting life cycle, soil-improvement effects, potential cultivation in both 
agricultural lands and pastures, low establishment costs etc. factors have made alfalfa the "queen of the feeds" (Kamalak et al., 2005; Akmal et al., 2011). Alfalfa could be considered as an easy, cheap and rich source of feed for livestock industry. It is quite rich in crude protein and easily digested by ruminants (Radovic et al., 2009). Alfalfa is also highly rich in minerals and vitamins (Altınok and Karakaya, 2002). It is used in different forms in livestock industry including herbage, hay, silage, and pellet (Lacefield et al., 2009).

With high yield potential and adaptation capacity to different environmental and ecological conditions, alfalfa has quite a large genetic diversity (Hill et al., 1988). Soil fertility, genetic diversity, weeds, harvest dates and number of harvests, growing techniques, pesticides, climate conditions and cultural practices significantly influence herbage yield and quality of alfalfa (Petkova and Panayotova, 2007; Butnariu et al., 2012). Researchers mostly focus on chemical composition of the feeds including the parameters of crude protein, crude ash, acid detergent fiber (ADF), neutral detergent fiber (NDF), mineral contents, metabolic energy, and relative feed value (Kaplan et al., 2016).

New alfalfa cultivars were developed and served to markets continuously. New breeds should be experimented for yield and quality attributes under different climate and soil conditions. In this study, yield and quality traits of 16 alfalfa genotypes were determined and compared under Kayseri provincial conditions to identify high yield and quality genotypes to be grown in the region.

\section{MATERIALS AND METHODS}

In this study, 16 commercial alfalfa (Medicago sativa L.) cultivars (Verdor, Özpınar, Verko, Sünter, Kayseri, Savaş, Gea, Ömerbey, Magna-601, Alsancak, Başbağ, Nimet, Bilensoy, Magnum-5, Elçi, Gözlï) were used as the plant material of the experiments. Experiments were conducted in randomized blocks design with 3 replications over the experimental fields of Agricultural Research Center of Erciyes University in Kayseri province of Turkey. Kayseri province has a dominant temperate climate with hot and dry summers and cold and snowy winters. Experimental site has an altitude of $1054 \mathrm{~m}$. Temperature and precipitations of the experimental years were similar with the long-term averages, but relative humidity values were lower than the long-term averages. Experimental soils were sandy-loam in texture with slightly alkaline reaction $(\mathrm{pH})$, low lime and salt ratios. Soils were rich in potassium and phosphorus and poor in organic matter.

Sowing was performed on 21 October, 2014 as to have a sowing norm of $2.5 \mathrm{~kg} / \mathrm{da}$ (Anonymous, 2001). To facilitate emergence, alfalfa seeds were sown together with barley seeds $(1 \mathrm{~kg} / \mathrm{da})$. Plots were $5 \mathrm{~m}$ long and each plot had 8 rows (Engin and Mut, 2017). Row spacing was $25 \mathrm{~cm}$ (Gündel et al., 2014). A $2 \mathrm{~m}$ spacing was provided between the blocks and $40 \mathrm{~cm}$ spacing was provided between the plots to prevent interactions. Fertilization was practiced at sowing as to have $5 \mathrm{~kg} / \mathrm{da} \mathrm{N}$ and $10 \mathrm{~kg} / \mathrm{da} \mathrm{P}_{2} \mathrm{O}_{5}$ (Anonymous, 2001; Dumlu et al., 2017). Because of insufficient precipitations, sprinkler irrigation was practiced after sowing to secure emergence. Throughout the growing season, plants were irrigated 5 times as to bring soil moisture deficit to field capacity in each irrigation. Two manual weeding and one chemical treatment were practiced for weed control. Harvest was practiced at the beginning of flowering (10\%) (Manga et al., 2003). Two side rows and $50 \mathrm{~cm}$ sections from the top and bottom of each plot were omitted at harvest as to consider side effects. Remaining section was harvested, and green herbage yields were determined. Throughout the growing season, plants were harvested 4 times from $5 \mathrm{~cm}$ above the ground (Dumlu et al., 2017). 


\section{Current Trends in Natural Sciences}

Vol. 9, Issue 17, pp. 74-82, 2020

https://doi.org/10.47068/ctns.2020.v9i17.008

Current Trends in Natural Sciences (on-line)

ISSN: 2284-953X

Current Trends in Natural Sciences (CD-Rom)

ISSN: 2284-9521

ISSN-L: 2284-9521

ISSN-L: 2284-9521

Samples were dried at $70{ }^{\circ} \mathrm{C}$ for 48 hours. Dried samples were ground to pass through $1 \mathrm{~mm}$ sieve (Anonymous, 2001). For crude ash content, $1 \mathrm{~g}$ dry sample was ashed in an ash oven at $550{ }^{\circ} \mathrm{C}$ for 8 hours. Nitrogen $(\mathrm{N})$ content of dried samples was determined with the use of Kjeldahl method. Crude protein content was calculated with the use of $\mathrm{Nx6.25}$ formula (AOAC, 1990). For cell membrane components, NDF (Van Soest and Wine, 1967) and ADF (Van Soest, 1963) ratios were determined with the use of an ANKOM 200 Fiber Analyzer (ANKOM Technology Corp. Fairport, NY, USA) device.

Experimental data were subjected to analysis of variance with the use of SAS statistical software (System Software 9.0) over the totals of each harvest for green and dry herbage and crude protein yield and over the average of each harvest for crude protein, crude ash, ADF and NDF ratios (SAS Institute, 1999). Significant means were compared with the use of LSD test.

\section{RESULTS AND DISCUSSIONS}

Plant height, green and dry herbage and crude protein yields of alfalfa cultivars are provided in Table 1 . There were highly significant differences in these traits of the cultivars $(p \leq 0.01)$. The lowest plant height $(55.75 \mathrm{~cm})$ was obtained from Savaş cultivar and the greatest plant height $(84.83 \mathrm{~cm})$ was obtained from Kayseri cultivar, the average plant height was measured as $73.38 \mathrm{~cm}$.

Table 1. Plant height, green and dry herbage and crude protein yields of alfalfa cultivars

\begin{tabular}{lcccc}
\hline Cultivars & $\begin{array}{c}\text { Plant } \\
\text { Height }(\mathbf{c m})\end{array}$ & $\begin{array}{c}\text { Green Herbage } \\
\text { Yield } \mathbf{( k g / d a})\end{array}$ & $\begin{array}{c}\text { Dry Herbage Yield } \\
(\mathbf{k g} / \mathbf{d a})\end{array}$ & $\begin{array}{c}\text { Crude Protein } \\
\text { Yield (kg/da) }\end{array}$ \\
\hline Verdor & $72.25 \mathrm{f}$ & $6519.10 \mathrm{bc}$ & $1531.21 \mathrm{defg}$ & $258.77 \mathrm{cde}$ \\
Özpınar & $70.17 \mathrm{~g}$ & $6091.60 \mathrm{bcdef}$ & $1615.16 \mathrm{bcde}$ & $288.07 \mathrm{bcd}$ \\
Verko & $70.17 \mathrm{~g}$ & $5554.60 \mathrm{fg}$ & $1468.07 \mathrm{efgh}$ & $292.64 \mathrm{bc}$ \\
Sünter & $71.00 \mathrm{fg}$ & $5655.70 \mathrm{fg}$ & $1540.16 \mathrm{defg}$ & $283.88 \mathrm{bcd}$ \\
Kayseri & $84.83 \mathrm{a}$ & $5125.80 \mathrm{~g}$ & $1349.30 \mathrm{~h}$ & $243.04 \mathrm{e}$ \\
Savaş & $55.75 \mathrm{i}$ & $5834.00 \mathrm{def}$ & $1474.51 \mathrm{efgh}$ & $282.09 \mathrm{bcde}$ \\
Gea & $82.96 \mathrm{ab}$ & $7389.00 \mathrm{a}$ & $1878.86 \mathrm{a}$ & $349.40 \mathrm{a}$ \\
Ömerbey & $72.50 \mathrm{f}$ & $5880.10 \mathrm{cdef}$ & $1417.83 \mathrm{fgh}$ & $282.97 \mathrm{bcd}$ \\
Magna-601 & $70.92 \mathrm{fg}$ & $6125.30 \mathrm{bcdef}$ & $1574.03 \mathrm{cdef}$ & $281.02 \mathrm{bcde}$ \\
Alsancak & $76.00 \mathrm{e}$ & $6630.20 \mathrm{~b}$ & $1773.04 \mathrm{ab}$ & $318.68 \mathrm{ab}$ \\
Başbağ & $78.17 \mathrm{~d}$ & $6424.80 \mathrm{bcd}$ & $1694.56 \mathrm{bcd}$ & $302.57 \mathrm{~b}$ \\
Nimet & $80.67 \mathrm{c}$ & $6606.60 \mathrm{~b}$ & $1733.25 \mathrm{abc}$ & $290.60 \mathrm{bc}$ \\
Bilensoy & $81.43 \mathrm{bc}$ & $5674.50 \mathrm{efg}$ & $1415.45 \mathrm{fgh}$ & $258.82 \mathrm{cde}$ \\
Magnum & $63.41 \mathrm{~h}$ & $5650.00 \mathrm{fg}$ & $1343.41 \mathrm{~h}$ & $248.98 \mathrm{de}$ \\
Elçi & $72.42 \mathrm{f}$ & $6312.90 \mathrm{bcdef}$ & $1621.98 \mathrm{bcde}$ & $299.07 \mathrm{~b}$ \\
Gözlü & $71.42 \mathrm{fg}$ & $5615.30 \mathrm{fg}$ & $1404.62 \mathrm{gh}$ & $254.37 \mathrm{cde}$ \\
\hline Means & $\mathbf{7 3 . 3 8}$ & $\mathbf{6 0 6 8 . 0 9}$ & $\mathbf{1 5 5 2 . 2 2}$ & $\mathbf{2 8 3 . 4 4}$ \\
\hline LSD & $\mathbf{1 . 9 5}$ & $\mathbf{6 5 5 . 4 9}$ & $\mathbf{1 6 8 . 9 3}$ & $\mathbf{3 9 . 7}$ \\
\hline
\end{tabular}

The lowest green herbage yield $(5125.80 \mathrm{~kg} / \mathrm{da})$ was obtained from Kayseri cultivar and the greatest green herbage yield $(7388.96 \mathrm{~kg} / \mathrm{da})$ was obtained from Gea cultivar, average green herbage yield 


\section{Current Trends in Natural Sciences}

Vol. 9, Issue 17, pp. 74-82, 2020

https://doi.org/10.47068/ctns.2020.v9i17.008

Current Trends in Natural Sciences (on-line)

ISSN: 2284-953X

Current Trends in Natural Sciences (CD-Rom)

ISSN: 2284-9521

ISSN-L: 2284-9521

ISSN-L: 2284-9521

was calculated as $6068.09 \mathrm{~kg} / \mathrm{da}$. Dry herbage yields of alfalfa cultivars varied between 1343.41 $1878.86 \mathrm{~kg} / \mathrm{da}$ with an average value of $1552.22 \mathrm{~kg} / \mathrm{da}$. The lowest dry herbage yield was obtained from Magnum-5 cultivar and the greatest from Gea cultivar. Alsancak and Nimet alfalfa cultivars were also placed into the greatest dry herbage yield group. The lowest crude protein yield (243.04 $\mathrm{kg} / \mathrm{da})$ was obtained from Kayseri cultivar and the greatest crude protein yield $(349.40 \mathrm{~kg} / \mathrm{da})$ was obtained from Gea cultivar, the average crude protein yield was calculated as $283.44 \mathrm{~kg} / \mathrm{da}$.

Crude protein, crude ash, ADF and NDF ratios of alfalfa cultivars are provided in Table 2 . There were significant differences in these traits of alfalfa cultivars $(p<0.01)$. Crude protein ratios of alfalfa cultivars varied between $16.57-20.28 \%$ with an average value of $18.17 \%$. The lowest crude protein ratio was obtained from Nimet cultivar and the greatest crude protein ratio was obtained from Ömerbey cultivar. Verko cultivar $(19.89 \%)$ was also placed into the greatest crude protein ratio group. Crude ash ratios of the alfalfa cultivars varied between $9.41-10.52 \%$ with the lowest value in Nimet cultivar and the greatest value in Magnum-5 cultivar. Average crude ash ratio was calculated as 9.82\%. Özpınar, Gea, Alsancak and Başbağ cultivars were also placed into the greatest crude ash ratio group. The lowest ADF ratio was obtained from Magnum-5 cultivar (34.87\%) and the greatest ADF ratio was obtained from Kayseri cultivar $(42.27 \%)$. The average ADF ratio was calculated as $38.79 \%$. The NDF ratios of alfalfa cultivars varied between $46.89-55.21 \%$ with an average value of $51.21 \%$. The lowest NDF ratio was obtained from Magnum-5 cultivar and the greatest NDF ratio was obtained from Elçi cultivar. Magna-601 cultivar (47.74\%) was also placed into the greatest NDF ratio group.

Table 2. Biochemical properties of alfalfa cultivars

\begin{tabular}{lcccc}
\hline Cultivars & $\begin{array}{c}\text { Crude Protein } \\
\text { Ratio }(\boldsymbol{\%})\end{array}$ & $\begin{array}{c}\text { Crude Ash Ratio } \\
(\mathbf{\%})\end{array}$ & $\begin{array}{c}\text { ADF Ratio } \\
(\boldsymbol{\%})\end{array}$ & $\begin{array}{c}\text { NDF Ratio } \\
(\boldsymbol{\%})\end{array}$ \\
\hline Verdor & $16.99 \mathrm{ef}$ & $9.55 \mathrm{~cd}$ & $39.40 \mathrm{c}$ & $50.90 \mathrm{ef}$ \\
Özpınar & $17.47 \mathrm{def}$ & $10.19 \mathrm{ab}$ & $36.81 \mathrm{de}$ & $48.99 \mathrm{gh}$ \\
Verko & $19.89 \mathrm{ab}$ & $9.72 \mathrm{bcd}$ & $36.36 \mathrm{e}$ & $48.05 \mathrm{hi}$ \\
Sünter & $18.03 \mathrm{cde}$ & $9.73 \mathrm{bcd}$ & $40.24 \mathrm{bc}$ & $51.17 \mathrm{de}$ \\
Kayseri & $18.21 \mathrm{~cd}$ & $9.69 \mathrm{bcd}$ & $42.27 \mathrm{a}$ & $49.49 \mathrm{~g}$ \\
Savaş & $19.08 \mathrm{bc}$ & $9.43 \mathrm{~d}$ & $37.63 \mathrm{de}$ & $49.93 \mathrm{fg}$ \\
Gea & $18.41 \mathrm{~cd}$ & $10.05 \mathrm{abc}$ & $39.65 \mathrm{bc}$ & $54.92 \mathrm{a}$ \\
Ömerbey & $20.28 \mathrm{a}$ & $9.77 \mathrm{bcd}$ & $40.86 \mathrm{~b}$ & $52.21 \mathrm{~cd}$ \\
Magna-601 & $18.24 \mathrm{~cd}$ & $9.87 \mathrm{bcd}$ & $36.86 \mathrm{de}$ & $47.74 \mathrm{ij}$ \\
Alsancak & $17.90 \mathrm{de}$ & $10.03 \mathrm{abc}$ & $39.98 \mathrm{bc}$ & $54.25 \mathrm{ab}$ \\
Başbağ & $17.65 \mathrm{def}$ & $10.17 \mathrm{ab}$ & $39.70 \mathrm{bc}$ & $53.61 \mathrm{~b}$ \\
Nimet & $16.57 \mathrm{f}$ & $9.41 \mathrm{~d}$ & $40.20 \mathrm{bc}$ & $51.72 \mathrm{cde}$ \\
Bilensoy & $18.08 \mathrm{cde}$ & $9.48 \mathrm{~d}$ & $37.76 \mathrm{~d}$ & $51.91 \mathrm{cde}$ \\
Magnum-5 & $18.09 \mathrm{cde}$ & $10.52 \mathrm{a}$ & $34.87 \mathrm{f}$ & $46.89 \mathrm{j}$ \\
Elçi & $17.93 \mathrm{de}$ & $9.88 \mathrm{bcd}$ & $40.39 \mathrm{bc}$ & $55.21 \mathrm{a}$ \\
Gözlü & $17.94 \mathrm{de}$ & $9.60 \mathrm{~cd}$ & $37.62 \mathrm{de}$ & $52.35 \mathrm{c}$ \\
\hline Means & $\mathbf{1 8 . 1 7}$ & $\mathbf{9 . 8 2}$ & $\mathbf{3 8 . 7 9}$ & $\mathbf{5 1 . 2 1}$ \\
\hline LSD & $\mathbf{1 . 1 1}$ & $\mathbf{0 . 5 4}$ & $\mathbf{1 . 2 9}$ & $\mathbf{1 . 5 5}$ \\
\hline
\end{tabular}


In this study, yield and quality traits of different alfalfa cultivars were determined and compared. It was reported that yield and quality traits of alfalfa genotypes varied with the climate and soil conditions (Bull et al., 1992; Gemechu, 2012). Such a case revealed that yield and quality traits of alfalfa cultivars should be investigated under different ecological and environmental conditions. Significant differences were observed in investigated traits of present alfalfa cultivars $(\mathrm{p} \leq 0.01)$.

The traits of plant height, number of branches of root canopy, number of nodes, number of branches, and number of roots generally have positive correlations with green and dry herbage yields. Greater herbage yields are observed with increasing values of these traits (Jafari et al., 2003; Riday and Brummer, 2004). Genetics, climate and environmental factors had also significant effects on herbage yields (Altınok and Karakaya, 2002; Dumlu et al., 2017; Engin and Mut, 2017). Veronesi et al. (2010) reported significant effects of growth stage, number of harvests, leaf/shoot ratio, harvest moisture and type of harvest on dry biomass yield of alfalfa. Main shoot lengths of alfalfa were reported as between $30-120 \mathrm{~cm}$ varied with the genotypes and environmental conditions (Aka and Avcioğlu, 2003). Ullah et al. (2009) and Kebede et al. (2018) indicated that plant heights might be related to genotypic differences, Mohammadjanloo et al. (2009) reported significant effects of genetic differences and genetic $\mathrm{x}$ fertilization interactions on plant height of alfalfa.

Present plant heights varied between $55.75-84.83 \mathrm{~cm}$, green herbage yields between 5125.80 $7388 \mathrm{~kg} / \mathrm{da}$, dry herbage yields between 1343.41 - $1878.86 \mathrm{~kg} / \mathrm{da}$, crude protein yields between $243.04-283.44 \mathrm{~kg} / \mathrm{da}$. Present findings were similar with the values of Demiroğlu et al. (2008), Başbağ et al. (2009), Yeşil and Şengül (2009), Zang et al. (2009), Kavut et al. (2014) and Geleti et al. (2014) and were greater than the values of Petkova et al. (2003). Present green and dry herbage yields were similar with the values of Şeker (2003), Saruhan and Kuşvuran (2011) and Çaçan et al. (2018). Herbage yields were greater than the values of Demiroğlu et al. (2008) reported for some alfalfa cultivars. Differences were mainly attributed to differences in cultivar and environmental factors.

Environmental conditions and harvest frequency were reported to have significant effects on herbage yield and quality (Kallenbach et al., 2002). Leaf/shoot ratio, varying with the number of harvests, the time between two harvests and harvest dates, is an important criterion for herbage quality. Such a ratio could be used for selection of appropriate cultivars (Sheaffer et al., 2000). Crude protein content is the most significant nutritional components of alfalfa herbage and values generally vary with the harvest dates and leaf/shoot ratios (Anderson et al. 1973). Leaves have stable protein contents and protein levels are generally greater than the shoots. Leaf ratio at harvest is an important indicator of feed quality (Jung, 2005). Present crude protein ratios varied between $16.57-20.28 \%$. Present findings were similar with the results of Kamalak et al. (2005), Zang et al. (2005), Kiraz (2011), Saruhan and Kuşvuran (2011), Doležal and Skládanka (2014), Gündel et al. (2014) and Singh and Garg (2015).

Previous researchers indicated that protein and ash ratios should be increased and cellulose and cell membrane components (ADF and NDF) should be reduced to improve nutritional composition of alfalfa (Riday and Brummer, 2005; Dale et al., 2012; Kavut and Avcioğlu, 2015). Low ADF and NDF ratios are desired in animal feeds. Low ADF ratio indicates high digestibility and low NDF ratio indicates high feed consumption (Avc1 et al., 2007). Increasing ADF and NDF ratios generally result in decreased protein ratios. A high-quality alfalfa hay should have a NDF ratio of around 400 $\mathrm{g} / \mathrm{kg}$ DM and ADF ratio of around $310 \mathrm{~g} / \mathrm{kg}$ DM (Redfearn and Zhang, 2011; Kazemi et al., 2012). 
On the other hand, NDF ratio of alfalfa hay at full-bloom should be around $530 \mathrm{~g} / \mathrm{kg} \mathrm{DM}$ and ADF ratio should be around $410 \mathrm{~g} / \mathrm{kg}$ DM (Dunham, 1998). Genetic factors significantly influence ADF and NDF ratios (Katić et al., 2008) and significant variations were reported in ADF and NDF ratios of alfalfa cultivars. Present ADF ratios varied between $34.84-42.27 \%$ and NDF ratios between 46.89 - 55.21\%. According to Dunham (1998) quality classification, for ADF ratios, only one cultivar (Kayseri: 42.27\%) had low-quality and for NDF ratios, 4 cultivars (Elçi: 55.21\%; GEA: 54.92\%; Alsancak: 54.25\% and Başbağ: 53.61\%) had low quality. The others had quality herbage. Present ADF and NDF ratios were similar with the values of Avcı et al. (2011), Çaçan et al. (2015) and greater than the values of Old et al. (2016), Geleti et al. (2014) and Gashaw et al. (2015).

Crude ash is the remaining portion of unburnt dry matter and is commonly used as an indicator of mineral contents (Gençtan, 1998). Minerals play a significant role in various processes in animals (hormone synthesis, enzyme activity) and they should be taken externally since they were not synthesized in animal body (Ülger and Kaplan, 2016). Crude ash contents may vary with the type of feed (roughage or concentrate), plant species and cultivars, soil and climate conditions of the growing site (Gralak et al., 2006). Present crude ash ratios varied between $9.41-10.52 \%$. Present values were similar with the values of Kamalak (2005), Basbag et al. (2009) and greater than the values of Davodi et al. (2011) and Kiraz (2011). Such differences were attributed the differences in plant genetics, soil and climate conditions.

\section{CONCLUSIONS}

Present findings revealed that 16 alfalfa cultivars were quite different from each other in terms of herbage yields and biochemical characteristics. Among the present cultivars, Gea cultivar was found to be prominent for green herbage yield; Gea, Alsancak and Nimet cultivars for dry herbage yield; Gea and Alsancak cultivars for crude protein yield; Ömerbey and Verko cultivars for crude protein ratio; Magnum-5, Özpınar, Gea, Alsancak and Başbağ cultivars for crude ash ratio; Magnum-5 cultivar for low ADF ratio and finally Magnum-5 and Magna-601 cultivars for low NDF ratio. Based on present findings, Gea, Alsancak and Nimet cultivars are recommended for high dry herbage yield and crude protein ratios in Kayseri province and similar ecologies.

\section{ACKNOWLEDGEMENTS}

This study was supported by the Erciyes University Research Fund (grand No: FYL-2016-6979).

\section{REFERENCES}

Ahmad, J., Iqbal, A., Ayub, M., Akhtar, J. (2016). Forage yield potential and quality attributes of alfalfa (Medicago sativa L.) under various agro-management techniques. The Journal of Animal \& Plant Science, 26(2), 465-474.

Aka, M.A., Avcıoğlu R. (2003). Selçuk koşullarında 7 farklı yonca çeşidinin verim ve diğer bazı verim özellikleri üzerinde araştırmalar [Research on yield and some other yield characteristics of 7 different clover varieties under Selcuk conditions] Turkey V. Field Crops Congress, 13-17 Ekim, Diyarbakır, s. 533-536.

Akmal, M., Uzma, F., Asim, M. (2011). Crop growth in early spring and radiation use efficiency in alfalfa. Pakistan Journal of Botany, 43(1), 635-64.

Alam, A., Yamamoto, S., Kahn, N., Honna, T. (2009). Screening for agronomic performance of six indigenous cultivars of alfalfa (Medicago sativa) at Karina northern areas of Pakistan. Electronic Journal of Environmental, Agricultural \& Food Chemistry, 8(10).

Altınok, S. ve A. Karakaya. (2002). Forage yield of different alfalfa cultivars under Ankara conditions, Turkish Journal of Agriculture and Forestry, 26, 11-16.

Anderson, M. J., Fries, G. F., Kopland, D. V. Waldo, D. R. (1973). Effect of cutting date on digestibility and intake of irrigated first-crop alfalfa hay. Agronomy Journal, 65, 357-360. 


\section{Current Trends in Natural Sciences}

Vol. 9, Issue 17, pp. 74-82, 2020

https://doi.org/10.47068/ctns.2020.v9i17.008

Current Trends in Natural Sciences (on-line)

ISSN: 2284-953X

Current Trends in Natural Sciences (CD-Rom)

ISSN: 2284-9521

ISSN-L: 2284-9521

ISSN-L: 2284-9521

Anonim, 2001. Technical Instruction for Measuring Agricultural Values. Ministry of Agriculture and Rural Affairs, Seed Registration and Certification Center, Ankara/Turkey.

AOAC, 1990. Official Methods of Analysis. 15th ed. Association of Official Analytical Chemists, Washington, DC.US.

Avcı, M., Aktaş, A., Kılıçalp, N., Hatipoğlu, R. (2011). Development of synthetic cultivar of alfalfa (Medicago sativa L.) on the basis of polycross progeny performance in the Southern Anatolia. Journal of Food, Agriculture \& Environment, 9(2), 404-408.

Avcı, M., Cinar, S., Kizil, S., Kilicalp, N., Hatipoglu, R., Yucel, C., Yucel, H., Aktas, A. and Gultekin, R. (2007). Research on the hay yields and qualities of some alfalfa cultivars under Cukurova conditions. Proceedings of the $7^{\text {th }}$ National Field Crops Congress, pp. 281-284, Erzurum, Turkey.

Basbag, M., Demirel, R., Avci, M. (2009). Determination of some agronomical and quality properties of wild alfalfa (Medicago sativa L.) clones in Turkey. Journal of Food, Agriculture \& Environment, 7(2), 357-359.

Bull, J.K., Cooper, M., Delacy, I.H., Basford, K.E., Woodruff, D.R. (1992). Utility of repeated checks for hierarchical classification of data from plant breeding trials. Field Crops Research, 30, 79- 95.

Butnariu, M., Samfira, I. (2012). Free Radicals and Oxidative Stress, Journal of Bioequivalence \& Bioavailability, 4(3), 1.

Çaçan, E., Kökten, K., Kaplan, M. (2018). Determination of yield and quality characteristics of some alfalfa (Medicago sativa L.) cultivars in the East Anatolia Region of Turkey and correlation analysis between these properties. Applied Ecology and Environmental Research 16(2), 1185-1198.

Dale, L. M., Rotar, I., Thewis, A., Vidican, R., Florian, V., Ciure, A. (2012). Determination of alfalfa crude fiber, NDF, $\mathrm{ADF}$ and lignin content by nir spectrometry. Lucrări Ştiințifice, Universitatea de Stiinte Agricole şi Medicină Veterinară" Ion Ionescu de la Brad" Iaşi, Seria Agronomie, 55(1), 245-249.

Davodi, M., Jafari, A. A., Assadian, G., Ariapour, A. (2011). Assessment of relationships among yield and quality traits in alfalfa (Medicago sativa) under dryland farming system, Hamadan, Iran. Journal of Rangeland Science, 1(3), 247-254.

Demiroğlu, G., Geren, H., Avcıoğlu, R. (2008). Adaptation of different Alfalfa (Medicago sativa L.) Genotypes under Aegean Region conditions. Ege Üniversitesi Ziraat Fakültesi Dergisi, 45(1), 1-10.

Doležal, P., Skládanka, J. (2014). The effect of the stage of maturity of alfalfa (Medicago sativa L.) on the chemical composition and in sacco digestibility. Acta Universitatis Agriculturae et Silviculturae Mendelianae Brunensis, 56(1), 55-64.

Dumlu, S. E., Çakal, Ş., Aksakal, E., Mustafa, Uzun., Özgöz, M.M., Terzioğlu, K., Uyusal., P. Atıcı., M. Menteşe, Ö. (2017). Determination of The Performance of Alfalfa Variety Candidate in The Ecological Conditions of Erzurum. Alınteri Zirai Bilimler Dergisi, 32(2), 55-61.

Engin, B., Mut, H. (2017). Determination of Hay Yield and Some Quality Traits of Different Alfalfa Cultivars. YYU J Agr Sci, 27(2), 212-219.

Gashaw, M., Mengistu, A., Gelti, D. (2015). Biomass yield dynamics and nutritional quality of alfalfa (Medicago sativa) cultivars at Debre Zeit, Ethiopia. J. Agric. Res. Dev, 5, 120-127.

Geleti, D., Hailemariam, M., Mengistu, A., Tolera, A. (2014). Biomass yield potential and nutritive value of selected alfalfa (Medicago sativa L.) cultivars grown under tepid to cool sub-moist agro-ecology of Ethiopia. Journal of Agricultural Research and Development, 4(1), 7-14.

Gemechu Keneni. (2012). Genetic potential and limitations of Ethiopian chickpea (Cicer arietinumal) germplasm for improving attributes of symbiotic nitrogen fixation, phosphorus uptake and use efficiency, and adzuki bean beetle (Callosobruchus chinensis L.) resistance. PhD. Thesis. Addis Ababa University faculty of life science, Ethiopia.

Gençtan, T. (1998). Tarımsal Ekoloji [Agricultural Ecology]. Trakya University Faculty of Agriculture Field Crops Department Publications, Tekirdağ, Türkiye.

Gündel, F. D., Karadağ, Y., Çınar, S. (2014). A Research on Yield, Quality and Adaptation of Some Warm Season Perennial Legumes Under Çukurova Ecological Conditions. Gaziosmanpaşa Üniversitesi Ziraat Fakültesi Dergisi, 31(3), 10-19.

Hill, J.R., Shenk, J.S., Barnes, R.F. (1988). Breeding for yield and quality. In Hanson, A. A., Barnes, D. K. and Hill, R. R. (eds). Alfalfa and Alfalfa Improvement. Agronomy Monograph 29, ASA, pp. 809-825, Madison, USA.

Jafari, A., Nosrati Nigeh, M., Haidari Sharifabadm, H. (2003). Comparison of yield, morphological and quality traits in 18 ecotypes and varieties of alfalfa (Medicago sativa) grown under irrigated and nonirrigated conditions. Proceeding of the VIIth International Rangelands congress, pp.1403-1405, Durban, South Africa. 


\section{Current Trends in Natural Sciences}

Vol. 9, Issue 17, pp. 74-82, 2020

https://doi.org/10.47068/ctns.2020.v9i17.008

Current Trends in Natural Sciences (on-line)

ISSN: 2284-953X

Current Trends in Natural Sciences (CD-Rom)

ISSN: 2284-9521

ISSN-L: 2284-9521

ISSN-L: 2284-9521

Jung, H.G. (2005). Impact of alfalfa growth and development on forage quality traits. In Asa-Cssa-Sssa Annual Meeting Abstracts, (pp. 54-4) CD-Rom. Paper.

Kallenbach, R. L., Nelson, C. J., Coutts, J. H. (2002). Yield, quality, and persistence of grazing and hay-type alfalfa under three harvest frequencies. Argon. J. 94, 1094-1103.

Kamalak, A. D. E. M., Canbolat, O., Erol, A., Kilinc, C., Kizilsimsek, M., Ozkan, C. O., Ozkose, E. (2005). Effect of variety on chemical composition, in vitro gas production, metabolizable energy and organic matter digestibility of alfalfa hays. Livestock Research for Rural Development, 17(7), 1-7.

Kaplan, M., Üke, Ö., Kale, H., Sırac, Y., Çinar, O., Atalay, A.I. (2016). Effect of Vegetative Stages on Potential Nutritive Value, Gas Production and Methane of Teff Hay. I $\breve{g d \imath r}$ Üniversitesi Fen Bilimleri Enstitüsü Dergisi, 4 , $1-7$.

Katić S., Mihailović V., Milić D., Karagić Đ., Glamočić D., Jajić I. (2008). Genetic and seasonal variations of fibre content in lucerne. Proceedings of the XXVIIth EUCARPIA Symposium on Improvement of Fodder Crops and Amenity Grasses, Copenhagen, Denmark, 19-23 August 2007, 130-135.

Kavut, Y. T., \& Avcioglu, R. (2015). Yield and quality performances of various alfalfa (Medicago sativa L.) cultivars in different soil textures in a mediterranean environment. Turkish Journal of Field Crops, 20(1), 65-71.

Kavut, Y.T., Çelen, A.E., Topçu, G. D., Kır, B. (2014). An investigation on the yield and some yield characteristics of different alfalfa genotypes grown in different locations. Ege Üniversitesi Ziraat Fakültesi Dergisi, 51(1): 23-29.

Kazemi, M., Tahmasbi, A. M., Naserian, A.A., Valizadeh, R., Moheghi, M.M. (2012). Potential nutritive value of some forage species used as ruminants feed in Iran. African Journal of Biotechnology 11, 12110- 12117.

Kebede, G., Assefa, G., Feyissa, F., Tekletsadik, T., Minta, M., Tesfaye, M. (2018). Yield and quality of alfalfa (Medicago sativa). Results of Livestock Research, 147-161.

Kiraz, A. B. (2011). Determination of relative feed value of some legume hays harvested at flowering stage. Asian Journal of Animal and Veterinary Advances, 6(5), 525-530.

Lacefield, G.D., Ball, D.M., Hancock, D., Andrae, J., Smith, R. (2009). Growing Alfalfa in the South, 1-15.

Mohammadjanloo, M.M., Gholipouri, A, Tobeh, A., Mostafavi, H. (2009). Study of effects of different levels of nitrogen and potassium on yield and yield components of rain-fed lentil. Plant Ecophysiol, 2, 91-94.

Old, C. A., Oltjen, J. W., Miller, J. R., Ohanesian, N., Hinders, R. G., Vogt, W., Sapienza, D. A. (2016). Reliability of in vivo, in vitro, in silico, and near infrared estimates of pure stand alfalfa hay quality: Component degradability and metabolizability of energy. The Professional Animal Scientist, 32(4), 470-483.

Petkova, D., Panayotova, G. (2007). Comparative study of trifoliolate and multifoliolate alfalfa (Medicago sativa L.) synthetic populations. Bulg J Agr Sci 13, 221-224.

Petkova, D., Vlahova, M., Marinova, D., Atanasov, A. (2003). Breeding evaluation of transgenic lucerne (Medicago sativa L.) lines; Optimal Forage Systems for Animal Production and the Environment, 26-28 May (pp. 330-332), Pleven Bulgaria.

Radovic, D.J., Sokolovic, J., Markovic J. (2009). Alfalfa-Most important perennial forage legume in animal husbandry. Biot. in Ani. Husb. 25(5-6), 465-475.

Redfearn, D., Zhang, H., Caddel, J. (2014). Forage Quality Interpretations. Oklahoma Cooperative Extension Service, PSS-2117.

Riday, H., Brummer, E.C. (2004). Relationships among biomass yield components within and between subspecies of alfalfa. Genetic Reports 4, 1-7.

Riday, H., Brummer, E.C. (2005). Relationships among biomass yield components within and between subspecies of Alfalfa. Retrieved November 24, 2014, from http://naldc.nal.usda.gov/naldc/download.xhtml?id $=16387 \&$ content $=$ PDF.

Saruhan, V., Kuşvuran, A. (2011). Determınatıon of yield performances of some lucerne cultivars and genotypes under the Güneydoğu Anadolu region conditions. Ege Üniversitesi Ziraat Fakültesi Dergisi, 48(2), 133-140.

SAS, 1999. SAS User's Guide. Statistic. Statistical Analysis Systems Institute Inc., Cary, NC.

Sheaffer, C. C., Martin, N. P., Lamb, J. F., Cuomo, G. R., Jewett, J. G., Quering, S. R. (2000). Leaf and stem properties of alfalfa entries. Agronomy Journal, 92(4), 733-739.

Singh, D., Garg, A. K. (2015). Performance of public and private sector developed lucerne (Medicago sativa L.) varieties for forage yield and quality. Range Management and Agroforestry, 36(2), 225-228.

Şeker, H. (2003). Adaptation and Yield Trial of Some New Alfalfa Cultivars to Erzurum Ecological Condition. Atatürk Üniversitesi Ziraat Fakültesi Dergisi, 34(3). 


\section{Current Trends in Natural Sciences}

Vol. 9, Issue 17, pp. 74-82, 2020

https://doi.org/10.47068/ctns.2020.v9i17.008

Current Trends in Natural Sciences (on-line)

ISSN: 2284-953X

Current Trends in Natural Sciences (CD-Rom)

ISSN: 2284-9521

ISSN-L: 2284-9521

ISSN-L: 2284-9521

Ulger, I., Kaplan, M. (2016). Variations in Potential Nutritive Value, Gas and Methane Production of Local Sainfoin (Onobrychis sativa) Populations. Alınteri Zirai Bilimler Dergisi, 31(2), 42-47.

Van Soest, P.J. (1963). The use of detergents in the analysis of fibre feeds. II. A rapid method for the determination of fibre and lignin. Journal of the Association of Official Analytical Chemists, 46, 829-835.

Van Soest, P.J., Wine, R.H. (1967). The use of detergents in the analysis of fibrous feeds. IV. Determination of plant cell wall constituents. Journal of the Association of Official Analytical Chemists, 50, 50-55.

Veronesi, F., Brummer, E.C., Huyghe. C. (2010). Alfalfa. In: Boller B., Posselt U. K., Veronesi F. (eds.): Fodder Crops and Amenity Grasses. Series: Handbook of Plant Breeding, (Vol. 5, pp.395-437). Springer, New York, USA.

Younas, M., Yaqoob, M. (2005). Feed resources of livestock in the Punjab, Pakistan. Livestock Research for Rural Development 17(2), 67-74.

Zang, W. M., Wang, C. Z., \& Yang, Y. X. (2005). Production performance of different lucerne varieties in China. New Zealand Journal of agricultural research, 48(4), 481-488. 